\title{
The Efficacy of the Soil Conservation Technologies Used on the Slopes of Mount Rwenzori in Western Uganda
}

\author{
Nabalegwa Muhamud Wambede and Asaba Joyfred \\ Department of Geography and Social Studies, Kyambogo University Uganda \\ Email: nabalegwaa@gmail.com; asabajoyfred@yahoo.com
}

\begin{abstract}
This study examined the efficiency soil conservation technologies adopted under the current cropping systems on the slopes of Rwenzori Mountain. A cross sectional research design was used in this study. Transects of 100 meter wide, were drawn on six selected ridges within which 102 peasant farms with different conservation technologies were selected. The severity of erosion on the selected farms was assessed using the physical erosion indicators. The results indicated that terracing was the most dominant practice. This was followed by trash bunds, water diversion channels, water collection ditches and mulching. It was however evident that, despite the adoption of soil conservation by some highland farmers, soil erosion still remained high especially on farms where one conservation practice was used in isolation. It is therefore recommended that a more comprehensive soil conservation strategy involving the use of agronomic and mechanical methods of soil conservation be emphasized in the Rwenzori uplands.
\end{abstract}

Keywords: Erosion, Efficiency, cropping system and conservation technology

\section{Introduction}

Soil has been of particular interest to man since the beginning of organized agriculture many thousands of years ago. This is because of its role in crop production and environmental management. As medium for plant growth, the root soil-environment should be free from inhabiting factors. Other things that plants obtain from the soil include; the physical support, air, water, temperature moderation, protection from toxins and nutrient elements [1]. No single resource is more important to the achievement of sustainable agriculture than the soil, which contains the nutrients and stores water essential for plant growth [2]. Indeed the quality of soil largely determines the level of agricultural development, food production, and the quality of life for a large part of the population on the earth's surface [3]. Soil erosion by water is commonly recognized as one of the main reasons of land degradation worldwide [4]. Soil erosion rates, caused by water are highest in agro systems located in hilly or mountainous regions in less developed countries of the world [5]. The noticeable site effects of soil erosion such as rills and gullies together with changes in soil fertility and water storage capacity drastically reduce agricultural or forestry productivity [6]. In view of the losses caused by water erosion, the development and adoption of efficient soil conservation techniques is fundamental [7]. Efficient soil erosion control should; reduce the destructive processes occurring in top soil, improve infiltration of surface water into soil profile, thus improving water balance of eroded basins and increasing the amount of water available to plants; limit soil fertility deterioration caused by soil composition changes and removal of nutrients and organic matter from soil [8].

The history of conservation in Uganda shows that efforts geared towards soil conservation have often failed while the problem of soil erosion has continued to escalate. Although the severity of soil erosion problems in the cultivated parts of the highlands was realized as early as the 1920s and consequently conservation measures enforced there after [9], most of the conservation works that were introduced are today almost none existent [10] it was noted that initial soil conservation programs in Uganda failed due to lack of responsibility for soil conservation, lack of expertise in the subject area, and dependence on legislation and enforcement other than education for policy administration. In short, structural weaknesses failed the initial soil conservation programs established for this nation [11].

In Busongora County in particular, the problem of soil has reached alarming levels threatening the survival of peasant farmers therefore the need for argent mitigation measures. The county's total 
population that has grown from 280290 in 2004 to 338009 people in 2014 is concentrated in a fixed stretch of land between the mount Rwenzori National Park and Queen Elizabeth national park. This has exerted pressure on the fragile mountainous land, leading to over cultivation of the lower mountain slopes, encroachment on the steeper slopes and forest lands, resulting into accelerated soil erosion, reduced soil productivity, low crop yields, food shortages and poverty. Currently, efforts are being made to address the problem of soil degradation. The government of Uganda through relevant agencies such as the ministries of agriculture, lands, water and environment is continuously encouraging farmers to adopt soil conservation practices so as to improve land productivity and increase their agricultural yields. Unfortunately, in the Rwenzori region, these efforts are generally poorly funded with peasant farmers being left to fund conservation initiatives on their farms, including those that yield communal benefits as; water ways, cut-off drains, water diversion channels, soak pits and terraces. As such farmers' response to government's soil conservation efforts in the region has been considerably slow. For farmers to adopt a particular soil conservation practice, they must be convinced that it will produce the desired results in form of increased yields, in an appropriate time frame and they must have access to appropriate resources and skills [12]. In Busongora County however, the efficiency of the adopted soil conservation technologies is unknown. Thus, this absence of local data on the performance of the adopted soil conservation techniques constitutes a knowledge gap and highlights the need to evaluate the efficiency of these conservation technologies in the region in order to ascertain the most appropriate and technically efficient techniques in erosion control. Such knowledge is vital in making the necessary recommendations as to what soil conservation practices should be given argent attention by those implementing conservation programs to mitigate the problem of soil erosion. As such, this study evaluated the efficacy of the adopted soil conservation technologies in Busongora County on mount slopes of Rwenzori.

\section{Study Area}

The study area is located in the eastern part of Kasese district bordered by Bukonzo county in the west, Kamwenge District in the east, Kabarole District in the north and Bushenyi District in the south, (See Fig 1). The area's physical landscape is characterized by a low flat land in the northeast and south and a mountainous land rising to over $7500 \mathrm{ft}$ in the North West. It is part of the Rwenzori mountain region, which was subjected to the complex internal processes of faulting, folding and vulcanicity responsible for its striking relief drainage and geology. It has also been noted that the Rwenzori Mountains, are considered to be a recently raised horst within the rift valley and comprise of the undifferentiated gneisses of the Gneissic-Granulitic complex overlaid uncomfortably in places occupied by the younger pre-Cambrian rocks of the Toro super group. The rise of the mountain and the formation of the rift valley were as a result of a series of successive tectonic episodes reported to have started in the Miocene. During the major tectonic episode at about 8 million years ago, the floor of the rift valley which dominates the north eastern and southern parts of Busongora was down-thrown. Later around about 2.6 to 2.3 million years ago, another major tectonic event resulted into the emergence of the Rwenzori to considerable altitudes and into the formation of the present rift valley lakes of Edward in the southwest, George in the southeast and the Kazinga channel in the southern part of Busongora [13, 14 \& 15].

Important to note, is that the sharp contrast in relief between the mountainous North West and the low land south and north East of Busongora has had a bearing on land use practices and on the severity of erosion. As such the erosion risk is higher on the mountainous North West a phenomenon that calls for mitigation measures in the form of soil conservation if land has to be used sustainably.

Busongora County, as part of the larger Rwenzori Mountain experiences montane climate. Due to its location near the equator, the inter tropical convergence zone (ITCZ) lies close to the mountain range for most of the year and supplements it with heavy orographic rainfall. Available data indicates that Busongora county experiences two long wet seasons that is, March to May and August to December with mean monthly rainfall values of $104 \mathrm{~mm}$ and $83.6 \mathrm{~mm}$ respectively and two short dry seasons January to February and June to July with mean monthly rainfall values of $29.6 \mathrm{~mm}$ and $37.1 \mathrm{~mm}$ respectively. January is the driest month with a mean rainfall value of $28.3 \mathrm{~mm}$ while November is the wettest month with mean rainfall of $117.6 \mathrm{~mm}$ [16]. It is important to note that the more frequent rains over this mountainous area often cause rapid mass movements which are readily accelerated by human 
use of the mountain resources [17]. The low land north-eastern and southern parts of Busongora are however relatively dry due to their generally low relief, characteristic of the East African rift valley floor. In this study, the high intensity and frequency of rainfall in this mountainous region was presumed to be related to the high rates of erosion over the Busongora upland peasant farms, thus the need for soil conservation.

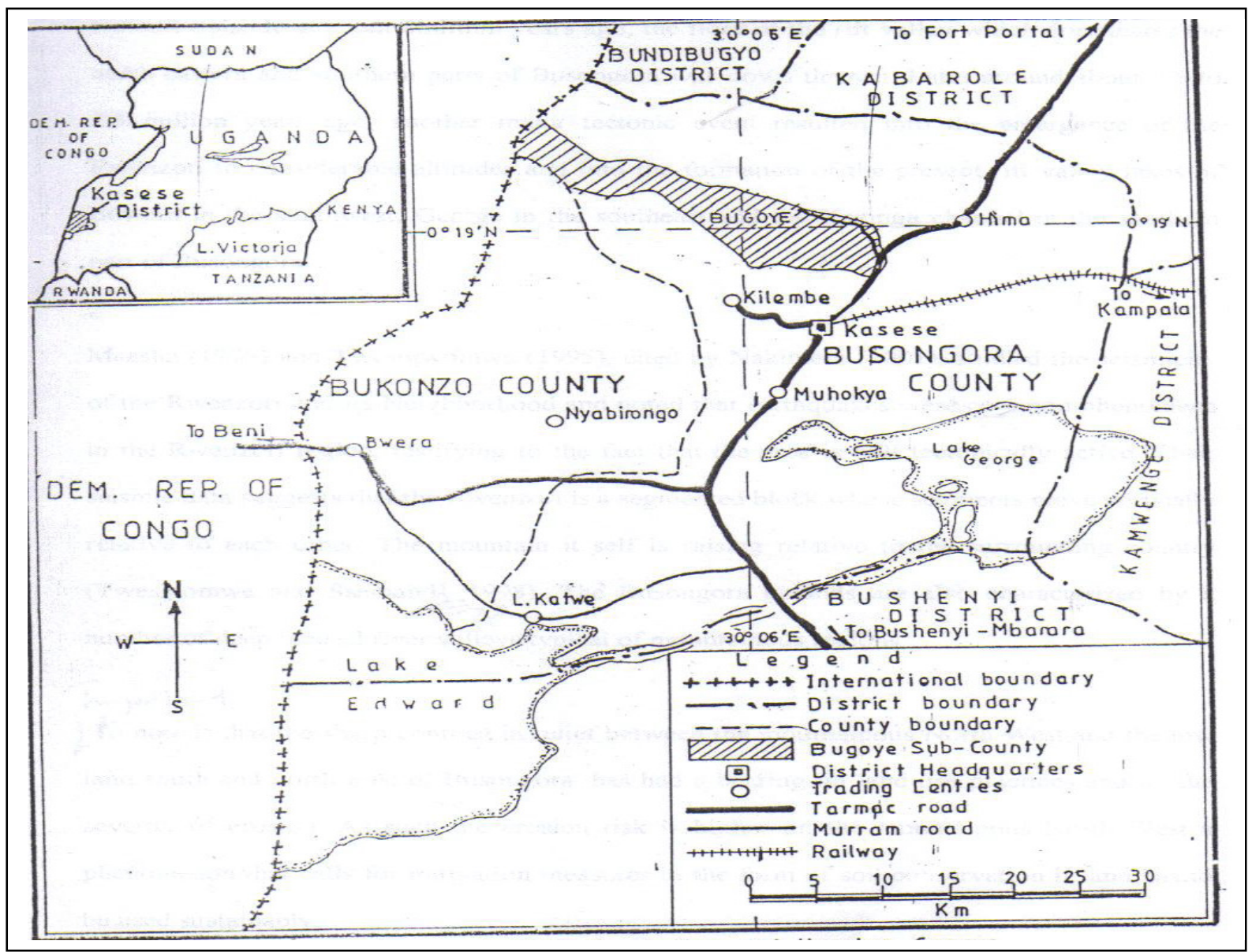

Source: Kasese District Map of 2002 Population and Housing Census

Figure 1.Map of Kasese district showing the location of Bugoye subcounty Busongora county Kasese district

Like any other mountainous region, soils in Busongora County are distributed largely according to topography and climate. Because of the effect of slope gradient, steep slopes have thin soils (lithisols), except at their base where alluvial fans develop. In line with this it was noted that higher elevations tend to have thin soils due to the fact that biochemical changes by soil organisms are sensitive to temperature changes as well as moisture [13]. As such areas of low temperatures and subsequently poor vegetation have thin soils implying that soil forming processes are more active at lower than higher elevations. Presently resource use over both the steep and gentle slopes in the form of cultivation, grazing, logging and road construction increases the dangers of soil erosion, hence the need for soil conservation. This study explores techniques that should be adopted by the Busongora upland peasant farmers to ensure that the fertility of soil, the only resource base for agricultural development is enhanced and sustained.

\section{The Study Methods}

Bugoye Sub-county, which is one of the most densely populated sub-counties in Busongora County, was purposively chosen as a representative sample for purposes of assessing the efficiency of the present soil 
conservation technologies in controlling erosion. The area also represents some of the most fragile and erosion prone slopes in Busongora and as such, requires urgent attention. To assess the efficiency of the existing soil conservation technologies in controlling erosion, three out of the five parishes in the sub county, Kibirizi, Muhambo and Bugoye were purposively chosen for study (See Fig 2). Six (6) ridges, namely Nyakajoro, Muramba, Bulindiguru, Kibirizi, Kyikubangali and Ndugutu were then selected from the three parishes taking two ridges from each parish to represent the rest of the sub-county. The ridges selected were those with relatively higher levels of agricultural activity and soil conservation. Each of the six ridges was then divided into three slope segments, namely, the upper slope, middle slope and lower slopes, at significant breakpoints along slope profiles, in line with Speight's morphological type classification. A longitudinal slope transect, 100 meters wide, was drawn along each of the six ridges. Site of the transect was chosen in a way that the most cultivated part of the slope with the highest number of farms under conservation was selected. A total of 102 farm plots with conservation practices were then chosen from the transects on the 6 ridges in such a way as to represent the slope facets and a range of slope angles. On the sampled farm plots measurement of the various variables namely; slope gradient, the height, width and spacing of terrace risers and trash bunds, depth of water diversion channels, water collection ditches and mulch depth, were made to determine their appropriateness to local farm conditions. The severity of erosion estimated from the measured dimensions of rills and observations of other visual indicators of erosion as; gullies, rain splash pedestals and exposed plant roots, was used as a measure of the efficiency of the current soil conservation technologies. Based on field measurements of rill erosion and observations of other physical erosion indicators, erosion on farm plots was characterized as slight, moderate and severe, according to the guide lines established by Land and Water Development Department, FAO [18], shown in Table 1. As such, Soil conservation was said to be inefficient over farm plots with moderate to severe erosion and efficient over farm plots with slight or no erosion.

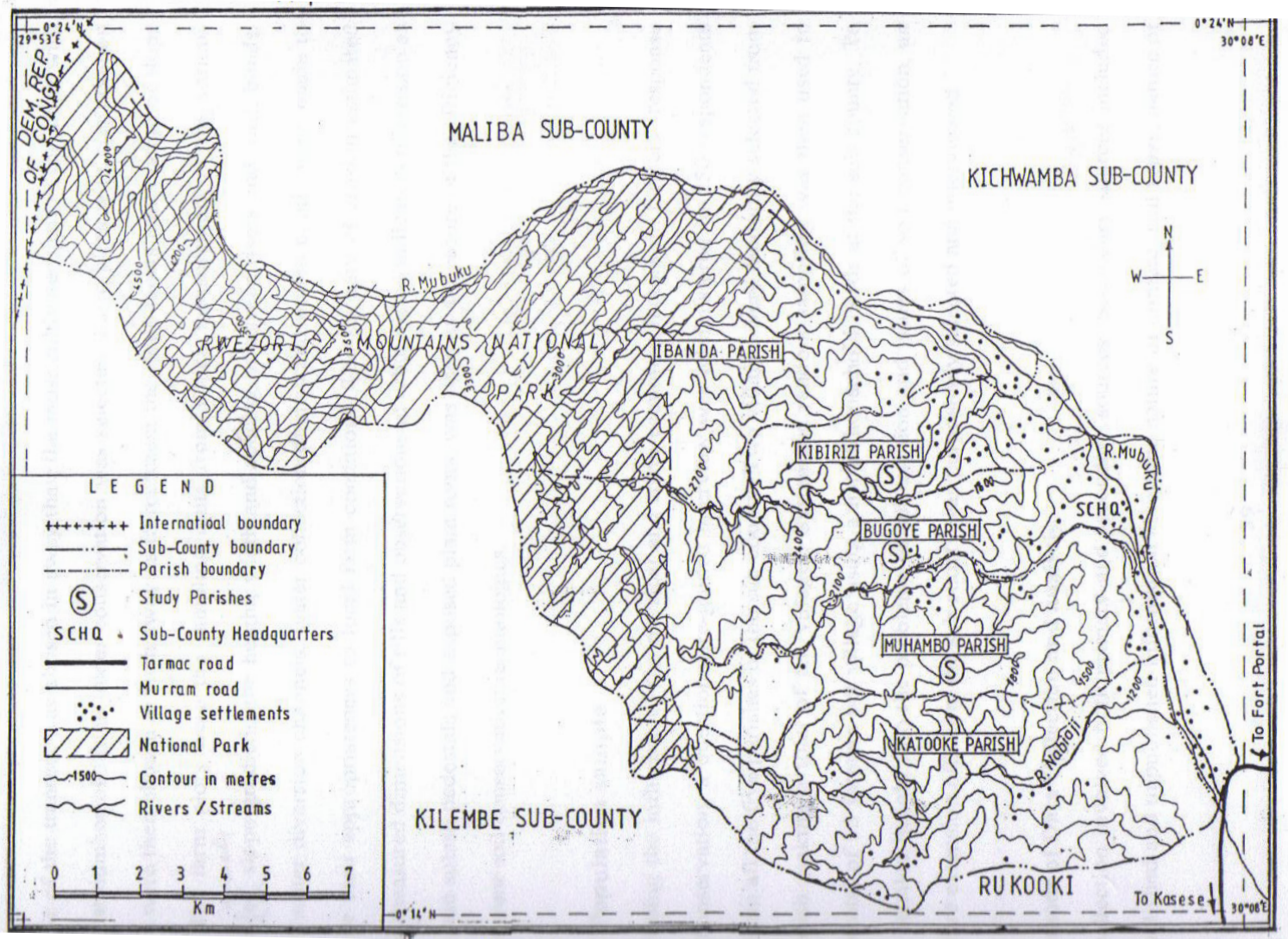

Adopted from: FAO (2000) Guidelines and reference material on integrated soil and nutrient management pp141146

Figure 2. Map of Bugoye subcounty showing the location of sampled parishes in Bugoye subcounty 
Table 1. Checklist for characterization of erosion severity based on the physical indicators of erosion

\begin{tabular}{ll}
\hline $\begin{array}{l}\text { Erosion severity } \\
\text { Characterization }\end{array}$ & Physical indicators of erosion \\
\hline 0. No erosion & -No evidence of visual erosion indicators \\
1. Slight erosion: & -Average Rill depth below $0.1 \mathrm{~m}$ \\
& -Little topsoil lost, no rain splash pedestals, no plant roots exposed, and no sub soil exposed. \\
& -Areal extent of rill erosion is $5 \%$ of the plot. \\
2. Moderate erosion: & -Average rill depth of $0.1-0.2 \mathrm{~m}$ \\
& -Evidence of topsoil removal but no sub soil exposed, exposure of Plant roots in topsoil in \\
& some parts. \\
& -Areal extent rill erosion is between $6-25 \%$ of the plot. \\
& -Average rill depth of $0.21-0.3 \mathrm{~m}$ \\
& -Severe loss of top soil, Existence of splash pedestals, exposure of Plant roots, Sub soil \\
& exposed. \\
& -Areal extent rill erosion is over $25 \%$ of the plot \\
\hline
\end{tabular}

\section{Results and Discussion}

\subsection{The Efficiency of Terraces on the upland Peasant Farms}

Table 2. Showing characterization of terrace risers by spacing

\begin{tabular}{|c|c|c|c|c|c|c|c|c|c|c|c|c|c|c|c|c|c|}
\hline \multirow{2}{*}{$\begin{array}{l}\text { Slope } \\
\text { Transact } \\
\text { Ridge }\end{array}$} & \multicolumn{3}{|c|}{$\begin{array}{l}\text { Mean farm } \\
\text { plot angle \% }\end{array}$} & \multicolumn{3}{|c|}{$\begin{array}{l}\text { Number of } \\
\text { Terraces. }\end{array}$} & \multicolumn{3}{|c|}{$\begin{array}{l}\text { Mean Terrace } \\
\text { Risers' height }\end{array}$} & \multicolumn{3}{|c|}{$\begin{array}{l}\text { Mean Terrace } \\
\text { risers' spacing }\end{array}$} & \multicolumn{3}{|c|}{$\begin{array}{l}\text { Characterization } \\
\text { by spacing }\end{array}$} & \multirow{2}{*}{$\begin{array}{l}\text { Total } \\
\text { Number } \\
\text { Terraces }\end{array}$} & \multirow{2}{*}{$\begin{array}{l}\text { Total } \\
\text { Number } \\
\text { Farm Plots }\end{array}$} \\
\hline & $\mathrm{LS}$ & MS & US & $\mathrm{LS}$ & MS & US & LS & MS & US & LS & MS & US & $\mathrm{S}$ & $\mathrm{AB}$ & $\mathrm{BS}$ & & \\
\hline Muramba & 17.3 & 31.3 & 57.2 & 8 & 19 & 6 & 0.73 & 1 & 0.9 & 18.1 & 15 & 12.9 & 2 & 13 & 0 & 32 & 15 \\
\hline Bulindiguru & 13.9 & 34.8 & 53.6 & 7 & 10 & 8 & 0.53 & 1 & 0.7 & 16.2 & 16.6 & 17.7 & 1 & 10 & 0 & 25 & 11 \\
\hline Kyikubangali & 12.6 & 41.2 & 57 & 4 & 8 & 5 & 0.55 & 63 & 0.75 & 17 & 19.4 & 13.6 & 1 & 6 & 0 & 17 & 7 \\
\hline Ndugutu & 13.8 & 35.6 & 56.9 & 4 & 11 & 6 & 0.65 & 1 & 0.9 & 17 & 15.4 & 16.2 & 0 & 9 & 0 & 21 & 9 \\
\hline Total & & & & & & & & & & & & & 5 & 52 & 2 & 134 & 59 \\
\hline Percentage & & & & & & & & & & & & & 8.5 & 88 & 3.4 & & \\
\hline
\end{tabular}

LS: Lower Slope MS: Middle Slope US: Upper slope

$\boldsymbol{S}$ : Standard slope $\boldsymbol{B S}$ : Below standard $\boldsymbol{A S}$ : Above standard

To assess the appropriateness and efficiency of the terracing conservation practice, measurements of terrace height and spacing in relation to farm plot slope angle were made over the 59 terraced farm plots randomly distributed over the six ridges. The standard formula which emphasizes the importance of slope in the spacing of terraces was used to calculate the standard terrace spacing values for the selected farm plots. The measured spacing values were then compared with the calculated standard values. Basing on the standard results obtained, terraces were characterized as standard (S), above standard (AS) and below standard (BS). Measurements of terrace heights and spacing are summarized in Table 2.

In terms of terrace spacing, the results summarized in Table 2 revealed that 52 farm plots, which are $88.1 \%$ of the 59 terraced farm plots chosen over the six transects, had over spaced terraces and were, therefore, characterized as above standard, only 5 farm plots, $8.5 \%$ had terraces whose average spacing was characterized as standard and two farm plots $3.4 \%$ had under-spaced terraces. The reason given by farmers for the widely spaced terraces was that they save the badly needed and scarce arable land that would otherwise be used up by close terraces. Even then, the interviewed farmers revealed that having close terraces would mean constructing more of the structures per farm plot, which would be so demanding in terms of labour and as such prove costly for poor farmers.

It should also be noted that terrace heights and spacing did not show any systematic change from 
lower through the middle to upper slopes. In many instances, farm plots with same slope angles registered differences in terrace heights and spacing. This confirms the fact that farmers did not follow any standard guidelines in constructing terraces over their farms. The same view is echoed by other researchers who observed that contour bunds in Rukiga were arranged arbitrarily other than being laid accurately laid along the contours, an indication of lack of technical knowledge necessary for designing appropriate soil conservation structures [19].

Soil conservation is meant to reduce the current erosion rate to tolerable levels and as such maintain land productivity and reduce sedimentation of streams channels down slope. The most important observed function of terrace risers on the upland arable farms of Bugoye sub- County was the trapping of runoff and sediment originating from the immediate up slope farm plots which would have otherwise caused serious sediment pollution in the streams at the bottom of the slope. In the area of study, successive terraces over upland farms combine to result in a net reduction in sediment deposited in river valleys, thus reducing the danger of sedimentation of streams that would otherwise affect water quality and also lead to serious flooding downstream over the low land areas of Bugoye. Indeed over the terraced farm plots runoff and eroded soil was observed to accumulate at the upper terrace ends there by facilitating water infiltration where the accumulated soils were deep enough. As such terraces on the upland farms of Bugoye sub-county play an important role in alleviating off site erosion effects. The contribution of terraces in trapping sediment over the Bugoye upland farms should, however, not be over emphasized. From the observations made and measurements taken, most of the terraces were found to be both over spaced and under-size. As observed the wide spacing of the terraces compromises their role in reducing slope length while their low heights compromise their ability to adequately trap sediment for a long time, so that the terraces are easily over run by high velocity run off from heavy rain storms making them unable to control erosion over upland peasant farms. Worse still, the wide spacing of the terraces allows run off to recollect in between the terraces within the farm plots thus gaining velocity and becoming very erosive before it meets the next terrace. As such, it is not uncommon to find large and deep rills in between two widely spaced terraces on a terraced farm plot.

In addition, observations and field measurements revealed higher terrace heights on the middle slopes and some sections of the upper slopes with deeper soils, while the steeper upper slopes with shallow stony soils had shorter under-sized terraces. The Construction and maintenance of sizable terraces over steep slopes is a big problem and indeed a challenge to soil conservation in mountainous areas. The effect of topography on soil formation provides an explanation on the difficulty conservationists are likely to face in trying to maintain sizable terraces on steeper slopes by arguing that; there is a tendency for material to remain in place on flat lands and gently sloping sites and for the pedo-unit to be thick but as slope angle increases so does the erosion hazard, resulting in thin soils on strongly sloping grounds [20]. The thin, stony soils obviously restrict terraces to only shorter heights making the practice inappropriate and inefficient over steeper mountain slopes. Given this observation, it is important to note that, though terraces appear to be reasonably satisfactory as a conventional conservation measure, they are not necessarily suited to all steeply sloping areas.

In analyzing the efficacy of terraces in the Rukiga highlands in Uganda, it was observed that there was a decline in terrace heights with increase in slope and it was noted that, while terrace heights on the Rukiga upland peasant farms increased from lower to middle slopes, they declined on the upper slopes. This was attributed to the low heights of terraces on steeper slopes to slope processes and it was argued that, on the lower slopes, transfer of soil down slope due to upslope cultivation is less dynamic but it increases on the middle slope due to the existence of reasonably deep soils. As such the loss of soil below the terrace increases the lower terrace walls to reasonable heights. But on the upper slopes where soil loss is even more dynamic the shallow soil depth limits the growth of terrace walls [19]. Temple cited by Morgan found terraces unsuitable for controlling erosion in the Ullugulu Mountains in Tanzania because the soil was found to be too thin so that their construction exposed the infertile subsoil thereby curtailing plant growth [21].

It was also observed that where the poorly maintained terraces were continuously over run by high velocity runoff, the upper terrace ends were filled up with sediment while the lower ends were modified into steep slopes due to continuous erosion. This over steeping of the lower terrace ends increases the velocity of runoff causing severe rill and sheet erosion, creating deep rills in case of sufficient soil depth and massive wash of soil up to bedrock or subsoil in case of shallow soil, thus causing severe crop destruction (see Plate 1). 


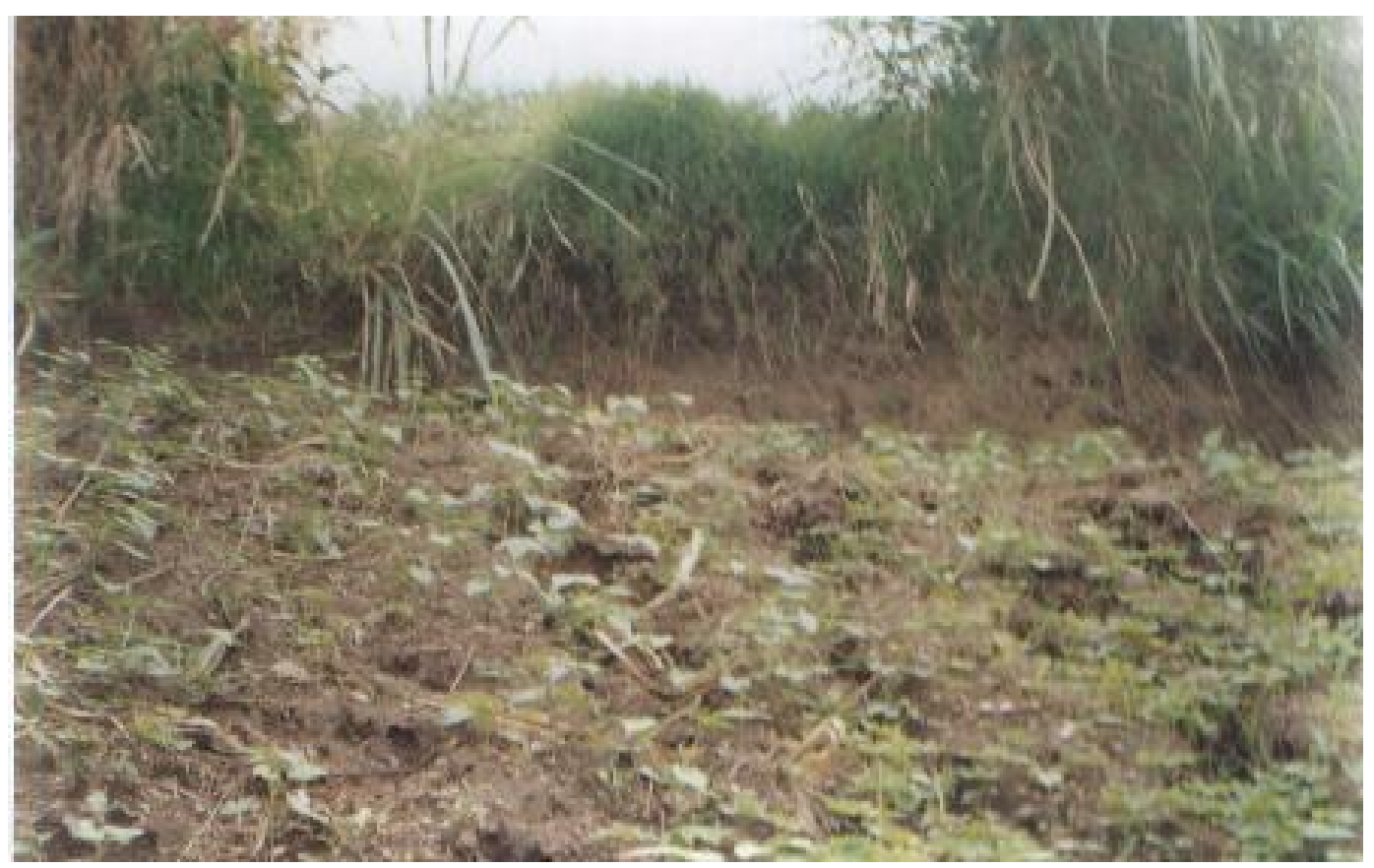

Plate 1. Severe rill erosion over a Beans farm plot caused by high velocity runoff flowing over the Steep lower terrace end on the Kibirizi middle slope.

The presence of poorly maintained terraces has indeed aggravated erosion problems on some Bugoye farm plots. Plate 1 above shows a poorly maintained modified bench terrace with over grown grass on a beans farm plot. As seen in the photograph, the lower terrace end has been over steepened by both cultivation and high velocity runoff and as such the steep slope created accelerates the speed of runoff increasing its erosive power leading to the development of large and deep rills and thus massive loss of soil and destruction of crops.

The results of this study generally revealed the fact that sizeable terraces can hardly be constructed and maintained on the steeper farm plots of Bugoye. As such conservationists should focus on combining terraces with other conservation techniques as cut off drains, diversion channels, mulching, soil cover crops, to ensure higher infiltration levels and a reduction in the amount of runoff, otherwise terraces alone will remain an inefficient method of controlling erosion.

To assess the extent of erosion on the terraced farms, a detailed analysis of erosion severity based on the physical indicators of erosion was done over 1 square meter micro plots randomly demarcated over selected terraced farm plots. The results of the measurements of rill depth, width and length over the three farm plots taken from each slope transect are given in Table 3.

Table 3. Measurements of rill dimensions on selected terraced farm plots

\begin{tabular}{|c|c|c|c|c|c|c|c|}
\hline \multirow[t]{2}{*}{$\begin{array}{l}\text { Slope transect } \\
\text { (Name of ridge) }\end{array}$} & \multicolumn{3}{|c|}{$\begin{array}{l}\text { Average Farm plot } \\
\text { Slope }(\%)\end{array}$} & \multirow{2}{*}{$\begin{array}{l}\text { Mean rill } \\
\text { Number } \\
\text { Per Sq.m }\end{array}$} & \multirow{2}{*}{$\begin{array}{l}\text { Mean rill } \\
\text { depth } \\
(\mathrm{m})\end{array}$} & \multirow{2}{*}{$\begin{array}{l}\text { Mean rill } \\
\text { width } \\
(\mathrm{m})\end{array}$} & \multirow{2}{*}{$\begin{array}{l}\text { Mean rill } \\
\text { length } \\
(\mathrm{m})\end{array}$} \\
\hline & $\begin{array}{l}\text { Lower } \\
\text { Slope }\end{array}$ & $\begin{array}{l}\text { middle } \\
\text { Slope }\end{array}$ & $\begin{array}{l}\text { Upper } \\
\text { Slope }\end{array}$ & & & & \\
\hline Nyakojoro & 16.5 & 40.2 & 51.8 & 3.7 & 0.14 & 0.12 & 0.65 \\
\hline Muramba & 17.0 & 47.6 & 50.0 & 3.3 & 0.21 & 0.21 & 0.88 \\
\hline Bulindiguru & 14.5 & 34.7 & 59.0 & 3.3 & 0.20 & 0.19 & 0.76 \\
\hline Kibirizi & 23.2 & 37.0 & 41.0 & 3.3 & 0.10 & 0.15 & 0.72 \\
\hline Kyikubangali & 12.9 & 43.0 & 55.2 & 3.7 & 0.18 & 0.11 & 0.70 \\
\hline Ndugutu & 14.0 & 38.2 & 53.6 & 3.3 & 0.19 & 0.16 & 0.83 \\
\hline
\end{tabular}


Rill erosion was observed to be the most dominant erosion type on the upland peasant farms of Bugoye. The dominance of rill erosion in the area of study is in itself an indicator of severe erosion levels. On the significance of erosion type in determining erosion severity, it has also been noted that, since rills and gullies remove larger volumes of soil per unit area than does sheet wash, the dominance of rill erosion indicates severe erosion rates. As such, the rill dimensions of depth, width, and length were measured over micro plots drawn on randomly chosen farm plots and used to classify erosion as slight, moderate and severe [22].

Generally the results in Table 4 show mean rill depth values ranging from $0.10-0.21 \mathrm{~m}$, mean rill width values between $0.11-0.21 \mathrm{~m}$ and mean rill length values of 0.65 to $0.88 \mathrm{~m}$. Muramba and Bulindiguru registered the highest erosion rates with Muramba registering a mean rill depth and width of $0.21 \mathrm{~m}$ and $0.20 \mathrm{~m}$, a mean rill length of $0.88 \mathrm{~m}$ and an average rill number of 3.3 rills per square meter. Bulindiguru registered $0.20 \mathrm{~m}$ and $0.19 \mathrm{~m}$ as mean rill depth and width, $0.76 \mathrm{~m}$ as mean rill length and an average rill number of 3.3 rills per square meter. Ndugutu had a mean rill depth and width of $0.19 \mathrm{~m}$ and $0.16 \mathrm{~m}$ respectively, a mean rill length of $0.83 \mathrm{~m}$ and an average rill number of 3.3 rills per square meter.

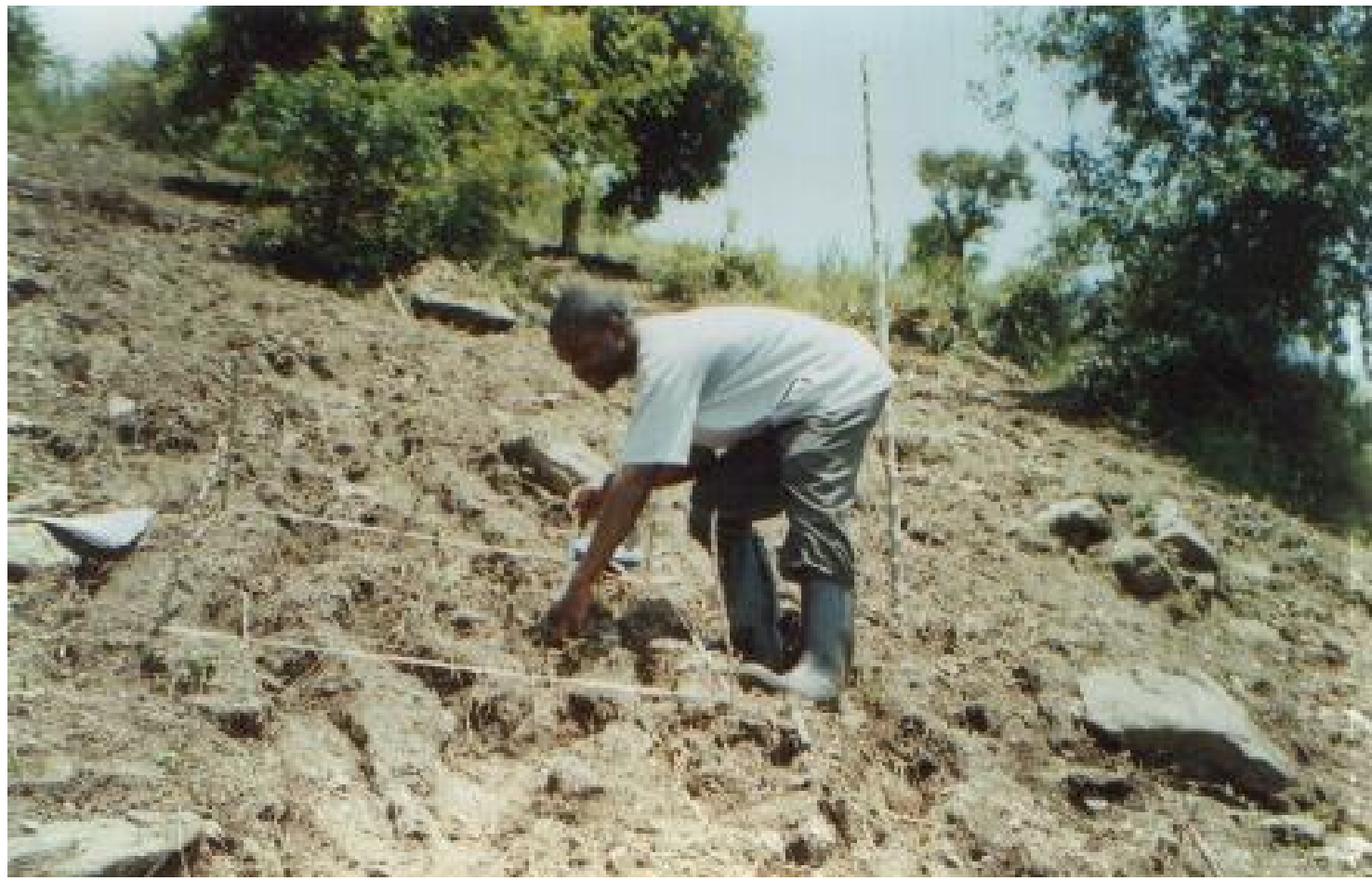

Plate 2. Measurements of the dimensions of the rills over a micro plot drawn on a freshly cultivated severely eroded cassava farm plot on the Muramba upper slope. The terrace is far below and was not captured.

These results reveal generally moderate to severe erosion rates over all the selected farm plots. The mean rill depth values for all the selected farm plots were found to be over $0.1 \mathrm{~m}$ indicating that erosion rates were all above the standard value for slight erosion and thus a threat to the growth of crops. In addition to being deep, the rills were also found to be considerably large. The implication of these rills with high depth, width and length values is that they act as drainage channels facilitating the transportation of large amounts of sediment leading to massive loss of soil from farmland and therefore severe erosion rates (see Plate 2). Indeed as observed, over areas affected by rill erosion the total sediment eroded is a reflection of the density and size of rills [23].

Terraces especially those on the upper slopes were found to be a failed venture for the Bugoye farmers. Plate 2 shows the researcher measuring the rill dimensions to estimate erosion severity on a farm plot and as seen in the photograph high velocity runoff was found to have formed deep and wide rills on land portions in between terraces. As already noted, farmers in Bugoye were found to locate terraces at considerable distance away from one another. Such wide terrace spacing allows runoff to accumulate in 
between the terraces thereby creating deep rills and destroying crops. In the photograph the rills formed by high velocity runoff were found to have swept the newly sowed seeds down slope causing a big loss to the farmer.

It is also important to note that while the measured rill dimensions were higher over Muramba, Ndugutu and Bulindiguru, they were slightly lower over the three other transects of Kyikubangali, Nyakajoro and Kibirizi. Kyikubangali registered $0.18 \mathrm{~m}$ and $0.11 \mathrm{~m}$ as mean rill depth and width; its mean rill length was $0.70 \mathrm{~m}$ while its average rill number was 3.7 rills. Nyakajoro had $0.14 \mathrm{~m}$ and $0.12 \mathrm{~m}$ as mean rill depth and width and $0.65 \mathrm{~m}$ as mean rill length and an average of 3.7 rills. Kibirizi registered an average rill number of 3.3 rills per square meter, a mean rill length of $0.72 \mathrm{~m}$ and $0.10 \mathrm{~m}$ and $0.15 \mathrm{~m}$ as mean rill depth and width respectively. Even then these values are still indicative of high erosion rates. In fact the estimated areal coverage of erosion over all the 18 farm plots selected for a detailed study was found to be over 10\%, thus indicating moderate to severe erosion in the area of study.

Analysis of erosion severity along the six selected ridges in relation to slope gradient revealed a strong relationship between slope gradient and rate of erosion. As already noted, rill depths were found to be lower over the upper steeper slopes and higher on farms over the middle and lower slope facets with gentle slopes. But despite these lower rill depths over the higher slopes, their rill widths were found to be larger and rill floors exposed the parent rock an indicator of severe erosion. The existence of shallow rills over steeper slopes is well explained by [21] who argues that over steeper slopes soils are shallow and stony due higher rates of erosion while those over less steeply sloping surfaces are deep with a high percentage of clay and other resistant minerals. It therefore follows that the occurrence of shallow rills over the upper slopes of Bugoye is a reflection of the dominance of shallow soils, which restrict rill formation only to shallow depths. In fact erosion was found to be more severe over farms located on the upper slope segments with steep slopes, than on the middle and lower slopes mainly because, on steep slopes, loss of even smaller amounts of soil through the shallow rills was found to leave behind a bare rock, making crop growth difficult. The exposure of the parent rock by rills on higher middle and upper slopes as observed in the area of study, is an indicator of the effect of erosion on plants, which need considerable soil depth grow and accounts for the low crop yields, occasional food shortages and poverty in Rwenzori region and Busongora in particular. This underscores the urgent need to intensify conservation measures over these steep slopes if life in this mountainous part of Uganda is to be sustained.

In addition, the results revealed the importance of cropping systems in erosion control. In Bugoye, erosion was found to be higher on farm plots with a single annual crop as cassava, beans, ground nuts, but lower over plots with mixed crops as cassava-ground nuts. Although not captured in micro plot analysis, field surveys revealed that erosion rates were even much lower over plots with a combination of annuals and perennials as on the banana-beans farm plots. The practice offers considerable protection to soil from rain droplet effect and checks on speed of runoff.

While rill erosion was found to be the most dominant type of erosion over the six ridges, it was found to occur together with sheet and rain splash erosion. Indeed part of the material transported by rills is derived from inter-rill areas and is moved into the rills by overland flow or rain splash [21]. Over steeper slopes where soils were too thin to allow the formation of deep rills, sheet erosion dominated, exposing rocky surfaces. Although not captured within the transects, gully erosion was occasionally found to occur in the farm boundaries due to poor disposal of runoff from diversion channels and terraces and in areas where footpaths released run off on to farm plots down slope.

It is, therefore, true to say that the terraces over the upland peasant farms of Bugoye only play the role of simply trapping sediment from up slope, thereby leading to the accumulation of soil at the upper terrace ends and reducing the amount of sediment delivered to streams and farm plots down slope. In fact observations and measurements of the physical indicators of erosion on the terraced farms in the area revealed that despite the existence of terraces, on-site point erosion in the form of rill and sheet erosion still remained high. Terraces in Bugoye were however found to be capable of trapping more soils over the lower slope segments than on the upper slopes but even here, their performance as erosion control structures was observed to be worsened by terrace failure so that in cases where terraces were overrun by high velocity runoff, the erosion rate was found to be severe probably more severe than it would have been had there been no conservation structures at all involving massive loss of soil and destruction of crops. Indeed some of the non-adopters cited the high erosion rates from the failed terraces as one of the reasons that discouraged them from constructing them on their farms. These 
observations relate to the findings [19] on the efficacy of terraces in Rukiga. He notes that terraces in Rukiga, hardly reduced the gradient of farm plots except at lower gradients so that the gradient of terraced farm plots remained steep and as a result point erosion too remained high. He thus observed that the efficacy of terraces in Rukiga increased on lower slopes.

All in all, although the terraces play an important role of trapping run off and sediments over the up land peasant farms, facilitating accumulation of soil at the upper terrace ends, and therefore reducing sediment pollution in the streams down slope, they have to a large extent been inappropriate to the local farm conditions and are inefficient in controlling on site point erosion on the up land farms of Bugoye. As such moderate to severe rill and sheet erosion still takes place in between successive terraces, leading to massive loss of soils, destruction of crops, a considerable reduction in soil fertility, reduced land productivity and thus occasional famine and persistent poverty a problem that requires agent attention of all conservationists.

\subsection{The Efficiency of Trash Bunds in Controlling Erosion}

Measurements of trash bund dimensions in Table 4 revealed that their average heights range from $0.16 \mathrm{~m}$ to $0.41 \mathrm{~m}$, while average spacing ranged from $10.7 \mathrm{~m}$ to $19.0 \mathrm{~m}$. The mean height and spacing values for the 16 farm plots with trash bunds were $0.27 \mathrm{~m}$ and $13.8 \mathrm{~m}$ for Nyakajoro, 0.21 and 15.3 for Muramba, $0.28 \mathrm{~m}$ and $16.9 \mathrm{~m}$ for Bulindiguru, $0.16 \mathrm{~m}$ and $19.5 \mathrm{~m}$ for Kibirizi, $0.19 \mathrm{~m}$ and 11.0 for Kyikubangali, $0.37 \mathrm{~m}$ and $12.2 \mathrm{~m}$ for Ndugutu.

Table 4. Showing trash bund dimensional measurements over five ridges

\begin{tabular}{lllll}
\hline $\begin{array}{l}\text { SlopeTransect } \\
\text { (Nameof ridge) }\end{array}$ & $\begin{array}{l}\text { Number of } \\
\text { Farm plots }\end{array}$ & $\begin{array}{l}\text { Mean farm plot } \\
\text { Slope (\%) }\end{array}$ & $\begin{array}{l}\text { Trash bund } \\
\text { Mean Height }(\mathbf{m})\end{array}$ & $\begin{array}{l}\text { Trash bund } \\
\text { Mean spacing (m) }\end{array}$ \\
\hline Nyakajoro & 04 & 25 & 0.27 & 13.8 \\
Muramba & 03 & 33 & 0.21 & 15.3 \\
Bulindiguru & 02 & 37 & 0.28 & 16.9 \\
Kibirizi & 01 & 24.8 & 0.16 & 19.5 \\
Kyikubangali & 03 & 29 & 0.19 & 11.0 \\
Ndugutu & 03 & 21 & 0.37 & 12.2 \\
\hline
\end{tabular}

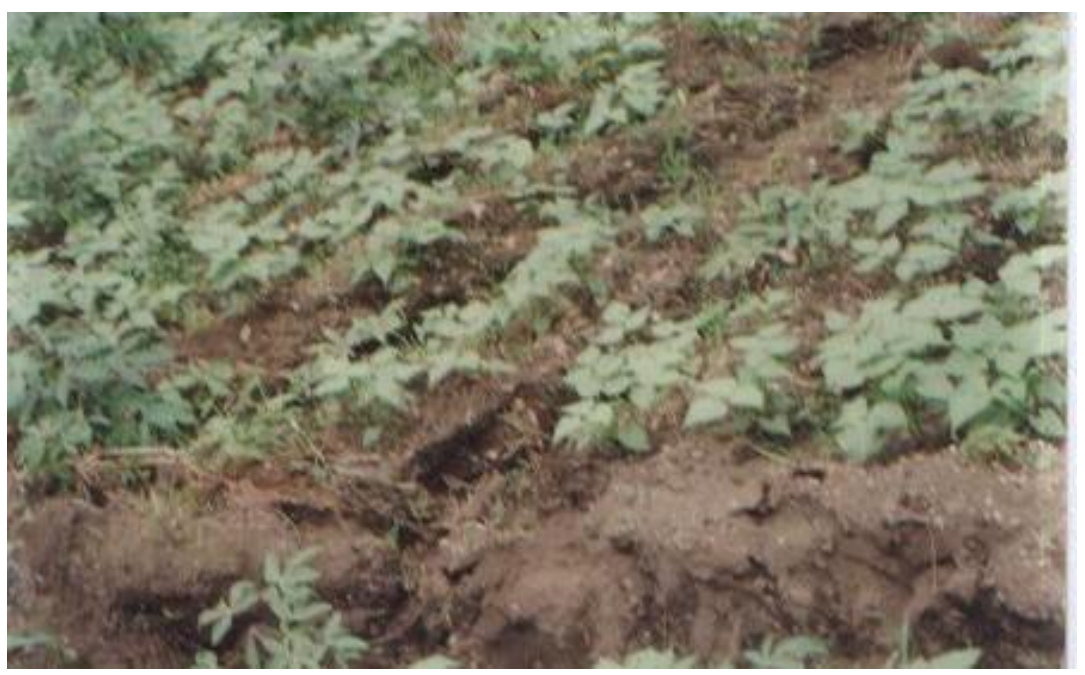

Plate 3. Severe erosion caused high velocity runoff flowing over submerged trash bund over a beans- cassava garden on the Nyakajoro middle slope. (One of the submerged bunds can be seen in the fore found)

As already noted, trash bunds in Bugoye are temporary structures that are destroyed every ploughing season and later reconstructed in the following season. It was observed that trash bunds common over the steeper middle and upper slopes are capable of trapping small amounts of soil and checking the 
speed of run-off over the upland farms. Their wide spacing, low heights together with the fact that they are used in isolation, compromises their ability to effectively serve as soil conservation structure over steep slopes where run-off velocities are high. In many cases severe rill and sheet erosion still take place in between the bunds. Over some farm plots trash bunds were found to be unable to control high velocity run-off from highly intensive rainfall and had therefore been over run, submerged and swept away. Erosion over such plots was found to be even more severe than it could have possibly been had there not been any conservation structures at all (see plate 3). As such, in their present form, trash bunds are largely inefficient in controlling erosion over slopes of Bugoye.

Although trash bunds are meant to trap run-off and reduce erosion rates, old bunds were found to be a liability to soil conservation efforts. Plate 3 shows an old trash bund (in the fore ground) that has been submerged and over run by run-off. As seen in the photograph water running down slope in welldefined rills submerges and cuts through the already weakened trash bund causing even more severe erosion. This is evidence that trash bunds are unsuitable for controlling erosion over steep slope where water velocities are high. As such where their use is inevitable trash bunds should not be used in isolation.

\subsection{The Efficiency of the Water Diversion Channels in Controlling Erosion}

Measurements of depths of water diversion channels over the 11 farm plots randomly distributed over 5 transect revealed that the channels over the upland peasant farms of Bugoye were too shallow, ranging from $0.17 \mathrm{~m}$ to $0.32 \mathrm{~m}$. A standard diversion channel should be at least 1.5 feet, which is $0.45 \mathrm{~m}$. But as can be seen from the results in Table 5, all the channel depths were below this average and were thus characterized as below standard.

Table 5. Dimensional measurements of water diversion channels

\begin{tabular}{lllll}
\hline $\begin{array}{l}\text { Slope transect } \\
\text { (Name of ridge) }\end{array}$ & $\begin{array}{l}\text { Number of } \\
\text { Farm plots }\end{array}$ & $\begin{array}{l}\text { Farm plot mean } \\
\text { Slope angle }(\%)\end{array}$ & $\begin{array}{l}\text { Mean channel } \\
\text { Depth }(\mathbf{m})\end{array}$ & $\begin{array}{l}\text { Mean channel } \\
\text { Width }(\mathbf{m})\end{array}$ \\
\hline Nyakojoro & 02 & 12.7 & 0.32 & 0.21 \\
Muramba & 03 & 17.4 & 0.23 & 0.26 \\
Kibirizi & 03 & 15.5 & 0.21 & 0.18 \\
Kyikubangali & 01 & 11.6 & 0.17 & 0.23 \\
Ndugutu & 02 & 10.2 & 0.24 & 0.22 \\
\hline
\end{tabular}

In Bugoye sub-County the observed diversion channels are meant to dispose run-off from cultivated fields at a non-erosive velocity. Although these structures are capable of controlling erosion in the early stages after their construction when they are still deep enough, their sitting still remains a big problem. In terms of siting the diversion channels were found to be inappropriately sited. In principle the diversion the diversion channels should be dug along the break points of the slope, either where a plateau changes into a steep slope or where along slope changes into a flatter land so as to collect water before it becomes erosive. In Bugoye, however, the channels were found to be sited haphazardly far below break points in slopes therefore allowing run-off to gain velocity and become very erosive forming rills before it reaches the channel. Even then some of the diversion channels were found to be located at lower sections of the farm plots, thus protecting only a small part of the farm plot from erosive run-off. Observations also revealed that farmers are not always mindful of the need to discharge collected run-off appropriately and as such run-off is often discharged on to erosive farm plot boundaries and foot paths which later develop into gullies causing severe erosion.

In terms of design, the walls of the channels were found to have been dug in a rectangular form with vertical walls making them susceptible to collapsing under heavy rains, thereby filling up with sediment causing over spills and severe rill erosion. In principle, channel walls are meant to be inclined at an angle to avoid the risk of channel walls collapsing. In addition while diversion channels should be graded in a way that allows them to transport water and sediment off the farm without causing erosion, evidence from the newly constructed channels over the upland peasant farms of Bugoye revealed that most of them were nearly flat with some depressions that encourage water and sediment accumulation, 
facilitating channel silting and over spills aggravating the soil erosion problem (See Plate 4). The wide spacing between the diversion channels also leaves land between the channels prone to severe erosion. Some channels were also found to have been filled up with sediment and therefore, no longer operational as conservation structures.

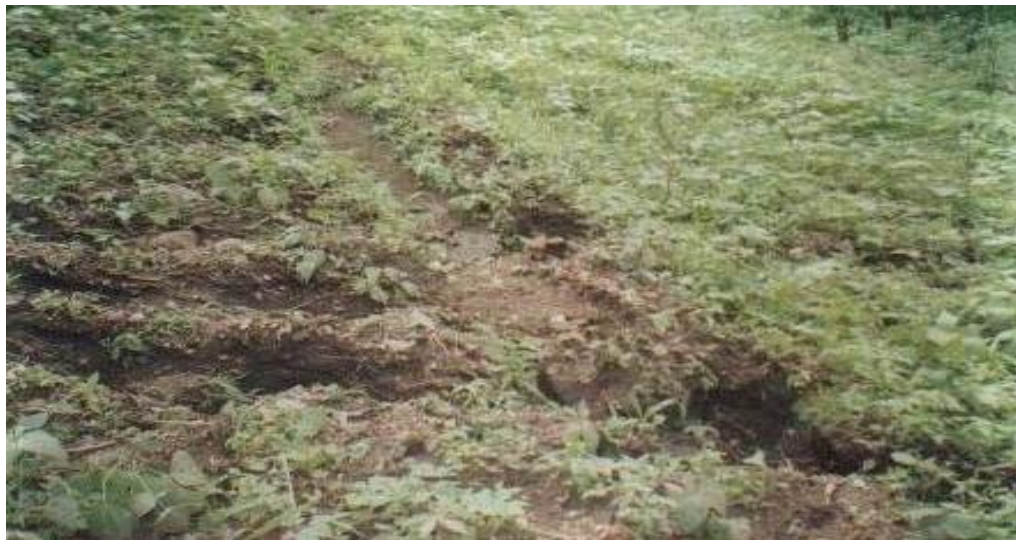

Plate 4. An over silted water diversion channel initiating severe rill erosion down slope in a Beans-garden on the Kyikubangali lower slope.

Water diversion channels in Bugoye were indeed found to betray the very purpose for which they are meant. Plate 4 above shows a shallow highly silted diversion channel in a beans garden. As seen in the photograph, run-off from upslope has broken through the diversion channel there by creating large and deep rills leading to massive loss of soil and destruction of crops. In fact the crops that were in the areas now occupied by the rills have been washed down slope. Unless the designs of these channels are improved, the structures will remain a liability to the farmers.

Since only well designed and maintained channels are capable of controlling erosion effectively, the poor maintenance and therefore shallow depths of the diversion channels in Bugoye have limited their ability to hold water from intensive storms and as such the water diversion channels over the Bugoye upland farms were found to be inappropriate to the local farm conditions and inefficient in controlling erosion.

\subsection{The Efficiency of Water Collection Ditches in Controlling Erosion}

The average depth values of water collection ditches over the 10 farm plots were found to be ranging from $0.19 \mathrm{~m}$ to $0.32 \mathrm{~m}$ while the diameter values ranged from $0.65 \mathrm{~m}$ to $1.2 \mathrm{~m}$. Table 6 shows the mean depth and diameter values for water collection ditches on selected farm plots over the five ridges.

Table 6. Mean depth values for water collection ditches

\begin{tabular}{lllll}
\hline $\begin{array}{l}\text { Slope Transect } \\
\text { (Name of Ridges) }\end{array}$ & $\begin{array}{l}\text { Number of } \\
\text { Farm plots }\end{array}$ & $\begin{array}{l}\text { Mean farm plot } \\
\text { Slope angle (\%) }\end{array}$ & $\begin{array}{l}\text { Water Ditches } \\
\text { Mean depth }(\mathbf{m})\end{array}$ & $\begin{array}{l}\text { Water Ditches } \\
\text { Mean Diameter }(\mathbf{m})\end{array}$ \\
\hline Nyakojoro & 03 & 25.4 & 0.25 & 0.76 \\
Muramba & 02 & 18.0 & 0.21 & 0.71 \\
Bulindiguru & 03 & 15.3 & 0.28 & 1.20 \\
Kyikubangali & 01 & 12.2 & 0.19 & 1.11 \\
Ndugutu & 01 & 21.9 & 0.32 & 0.65 \\
\hline
\end{tabular}

Water collection ditches are meant to collect run-off during a rainstorm, store it and allow it to infiltrate safely before it becomes erosive. Observations and measurements on existing water collection ditches revealed that most of these were shallow in depth and narrow in diameter. Characterization of conservation structures in the banana based micro-catchments of the lake Victoria shore region reveals that, for soak pits to be effective in accommodating water from heavy rain storms, it is recommended that they should be $0.8-1 \mathrm{~m}$ in depth and $2-3 \mathrm{~m}$ in diameter; but as can be seen from the measurements of 
the water collection ditches in this study, the depth and diameter values are far below these recommended minimum standards [24]. The observed risk associated with this deficiency is that the pits very often cause over spills during heavy rains and as the over spilling water flows down slope in a massive way, it often creates large rills in areas of deep soils, aggravating the problem of soil erosion. Generally although pitting in Bugoye is capable of accommodating water from short and less intense rainstorms, it was observed to be inefficient in controlling erosion during heavy intensive storms given their shallow depths.

\subsection{The Efficiency of Mulching in Controlling Erosion}

Measurements of much depth over the six mulched farm plots revealed that average mulch depth values range from $1.5 \mathrm{~cm}$ to $2.8 \mathrm{~cm}$, an indication of shallow mulching over all the plots. Most of the mulched plots also had patches of bare ground and mulches were generally thin and scattered. Table 7 shows the average mulch depth values over the selected farm plots.

Table 7. Measured mulch Depth values in relation to slope

\begin{tabular}{llll}
\hline $\begin{array}{l}\text { Slope Transect } \\
\text { (Name of ridge) }\end{array}$ & $\begin{array}{l}\text { Number of } \\
\text { Farm Plots }\end{array}$ & $\begin{array}{l}\text { Mean Farm } \\
\text { Plot Slope (\%) }\end{array}$ & $\begin{array}{l}\text { Average Mulch } \\
\text { Depth (cm) }\end{array}$ \\
\hline Muramba & 02 & 12.1 & 1.7 \\
Bulindiguru & 01 & 14.1 & 2.5 \\
Ndugutu & 03 & 11.7 & 2.2 \\
\hline
\end{tabular}

Over the farm plots where mulching is practiced, the mulching materials were found to be inefficient in controlling rain splash erosion and checking the speed of run-off to prevent rill and sheet erosion. As seen from Table 7, mulch depth values over the Bugoye farm plots are low and the mulches were found to be scattered on the farm plots leaving out portions of land unprotected from raindrop effect and offering little residence to high velocity run-off which sometimes sweeps the mulches down slope causing sheet erosion (Plate 5). The inefficiency of the mulching practice in controlling erosion is aggravated by the fact that it is in most cases the only conservation practice on the farm plot, yet it is recommended that mulching be used together with physical structures as water diversion channels, terraces to check the speed of run-off.

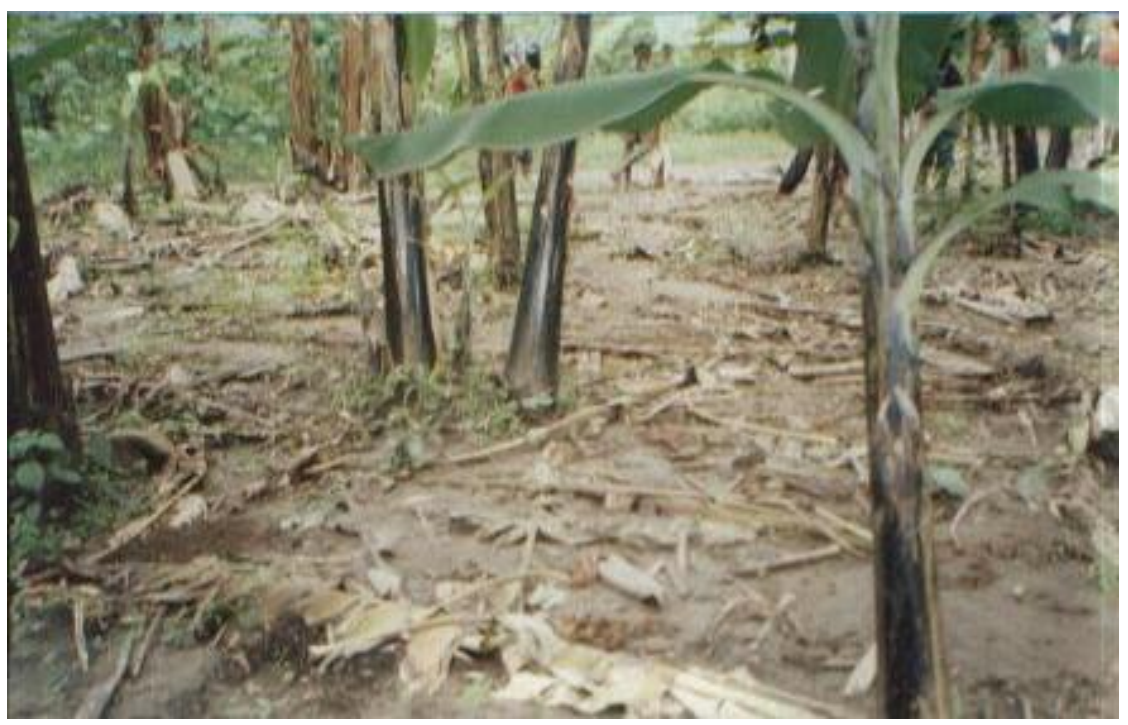

Plate 5. Sheet erosion caused by run-off sweeping mulches over a thinly mulched Banana farm plot on the Bulindiguru lower slope.

Although mulching is recommended as suitable for lower slopes, the practice needs a lot of 
improvement in Bugoye. Plate 5 above shows a thinly mulched Banana garden where most of the mulches have been washed down slope by accumulated run-off released from farm plots upslope. The application of mulches in isolation without physical conservation structures exposes mulches to great volumes of run-off and as such the thin mulches are easily swept away causing severe rill erosion that exposes the banana roots, weakens the banana plants, making them susceptible to falling, a problem that needs attention.

All in all, the performance of the present soil conservation technologies in use over the Bugoye upland farms leaves a lot to be desired and in their present form one is right to assert that they are to a large extent inefficient in controlling erosion over the peasant farm plots. This inefficiency is aggravated by the fact that most of the farmers use one conservation practice in isolation yet meaningful soil conservation should involve a combination of conservation practices for better results.

\section{Conclusion}

This study was undertaken in response to the lack of data on the performance of the present soil conservation technologies in the Rwenzori highlands in western Uganda and as such it generated large amounts of data on the appropriateness and efficiency of existing soil conservation practices. Based on the findings of the study the following conclusions are made.

The study revealed that farm plots with annuals cropping system, were the most erodible this is mainly because most of the annual crops as beans, cassava, Irish potatoes, ground nuts are poor soil cover crops offering very little protection to the soil and thus leaving them prone to severe soil erosion. This poses a serious challenge to soil conservation efforts given that the poor soil cover crops have a cultural bearing making up an important component in the diet of the local population.

As indicated by the results most of the erosion over the slopes of Busongora is attributed to poor land management, particularly lack of adequate permanent cover, poor terrace designs and improper disposal of run-off. A solution to these problems needs to be sought to retain the soil over these fragile lands so as save the farmers from future starvation.

In the assessment of the efficiency of soil existing soil conservation technologies, it was noted that terraces, the most dominant conservation practice on the Rwenzori highlands are inappropriate, that is to say, not constructed according to recommended standards. The fact that most of the terraces were found to be widely spaced and so brief in height robes them of the ability to effectively control soil erosion. Indeed the results indicate that despite the existence of these soil conservation structures on peasant farms, soil erosion still remained high. This underscores the fact that consideration of farm plot site specific factors in the designing conservation structures is a pre-requisite to their efficiency.

The study indicated that through time, the maintenance of terraces as soil conservation structures presents some problems to the farmers in that the accumulation of soil at the upper terrace end and the steeping of its lower end by both erosion and continuous digging results into terrace failure, severe erosion and destruction of crops. As such a solution to these problems has to be sought by those designing soil conservation programs.

The study has revealed that though terraces are capable of checking the speed of run-off and impounding soil lost from the up slope arable lands, they do not effectively control erosion. Their wide spacing allows run-off to recollect and gain velocity in between the two successive terraces there by becoming highly erosive, creating large rills and destroying crops. As such more aggressive conservation measures should be put in place and the need to have adequate vegetation and much cover particularly during the critical periods when rainfall is more intense but cover is lower as it is during the early stages of plant growth should be emphasized.

The study indicates that besides terraces other conservation structures as water diversion channels, trash bunds and water collection ditches only help collect run-off sediment from up slope but do not significantly reduce erosion on portions of the farm plot in between the structures. This leaves point erosion still high a phenomenon that requires agent attention.

In essence, the study has revealed that a single conservation measure cannot adequately control erosion. The physical conservation structures applied alone over upland peasant farms have proved inefficient in controlling erosion and as such a combination of agronomic and soil management measures together with appropriately designed and well maintained physical conservation structures as terraces, 
cut-off drains, water collection ditches is the most viable answer to the erosion problem in the highland areas.

\section{References}

1. M.W. Nabalegwa J. Asaba and R. Turyahanabwe. "Soil loss under different cropping system in Tropical Highlands, Uganda. Journal of Natural Resource Conservation". 4(1): 15-27, 2016.

2. L. Brader, "Sustainable Agriculture and Environment". In Achipale, E., Bakunda M.A., conservation in Europe. Land Use Policy 27, pp. 22-32, 1994.

3. M.W. Nabalegwa J. Asaba, "Socio-Economic Factors Affecting the Adoption of Soil Conservation Technologies on Rwenzori Mountain". Indonesian Journal of geography. IJG Vol. 47, No.1, pp. 26 - 39, 2015.

4. S.Beskow, C.R. Mello, L.D Norton, N. Curi, M.R.Viola \& J.C. "Avanzi, Soil erosion prediction in the Grande River Basin, Brazil using distributed modeling". Catena 79, 2009.

5. K. M. Widomski. "Terracing as a Measure of Soil Erosion Control and Its Effect on Improvement of Infiltration in Eroded Environment". Lublin University of Technology Poland, 2011.

6. T.Kuhlman, S. Reinhard, \& A. Gaaff, "Estimating the costs and benefits of soil conservation in Europe. Land Use Policy 27(1): 22-32. 2010.

7. A. C. R. Miranda, et al. "Assessment of Efficiency and Adequacy of Retention Terraces". Revista Brasileira de Ciência do Solo vol . 36. 2012.

8. C.Valentin, J. Poesenm \& Y. Li, "Gully erosion: Impacts, factors and control". Catena 63, pp. 132-153, 2005.

9. GOU, 1949. Soil Conservation Report 1941-1949. Uganda Protectorate.

10. B. Nakileza, "The influence of cropping systems and management practices on soil Erosion on mt Elgon slopes" Unpub thesis, Makerere University, 1992.

11. E.N.Nsubuga, "A critical Review on the Farmers' Response to Soil Conservation Policy in Uganda": In Rakakaikara, Silver, M.C., Bekunda, M.a., Tenywa, J.S (eds) Enhancing Farmers, efforts to combat soil degredation: Achallenge to Soil Science Technology. Proceedings of the $14^{\text {th }}$ conference of soil science society of East Africa, Mbarara, Uganda, 25, pp.1-10, 1994.

12. Obrien., "Economic Aspects of Sustainable Land Management, Regional Experience" Proceedings of the international board of soil research and management IBSRAM N0. 12 (2). Education for sustainable land management in the developing world Bangkok: IBSRAM. pp. 49-59

13. I. Nakimera, "The Impact of human activities and climate on the Vegetation in the Lake Victoria region and on the Rwenzori Mountain and its Neighbourhood". Unpub. PhD Thesis 2001, Faculty of Science Makerere University.

14. P.W.E Tanner. "The Stanley Volcanics of the Rwenzori, Uganda". In: Nakimera, Immaculate (ed), The Impact of human activities and climate on the Vegetation in the Lake Victoria region and on the Rwenzori Mountain and its Neghbourhood. Unpub. PhD Thesis. Faculty of science, Makerere University. 1970.

15. N. Maasha, The Seismicity of the Rwenzori Region in Uganda, In: Nakimera, Immaculate (ed), The Impact of human activities and climate on the Vegetation in the Lake Victoria region and on the Rwenzori Mountain and its Neghbourhood. Unpub. PhD Thesis, Faculty of science, Makerere University, 1975.

16. Department of Meteorology. "Ministry of Water, Lands and Environment, Uganda". (2007).

17. R. U. Cook, J.C Doornkamp. "Geomorphology in Environmental Management", Oxford University Press, 1990.

18. FAO. "Guidelines and Reference Material on Integrated Soil and Nutrient Management and Conservation for Farmer field Schools". Land and Nutrient Management Services. Lands and water Development Department, Rome. 2000.

19. D.K F. Bagoora, Assessment of runoff and soil loss on Peasant Upland farms and their Implications for Environmental Conservation in Rukiga Highlands Eastern Kabale District: Unpub phD Dissertation; Makerere University, 1997.

20. E. A.Fitz, Soils. "Their formation, Classification and distribution". Longman Group. United K. 1983.

21. P.H.Temple, "Sheet Wash Measurements on erosion plots at Mfumbwe, Eastern Ulluguru ountains, Tanzania: In Morgan R.P.C., 1986. Soil Erosion and Conservation. Longman Group, UK,limited 
22. R. G. Spomer, W.D. Shrader, P.E Rosenbery and E.L Miller, 1973. "Level terraces with Stabilized back walls on Loessial crop land in the Missouri valley". A cost effective study. Jounal of soil and water conservation 28,127-13. 1973.

23. R.P.C. Morgan, "Soil Erosion and Conservation". Longman Group, UK, limited. 1986.

24. L. P. Achan, "Biophysical and Socio-economic Factors Influencing Soil and Water Conservation Practices in the Banana Based Micro- catchment of the Lake Victoria Basin". Unpub MA Thesis; Makerere University, 2001. 